\title{
APRESENTAÇÃO DA PROF.` MARIA IVETE RIBEIRO DE OLIVEIRA POR OCASIÃO DA OUTORGA DO TÍTULO DE SÓCIO HONORÁRIO DA ABEn/1975
}

\author{
Amália C. Carvalho*
}

RBEn/03

CARVAlHO, A. C. - Apresentação da profa. Maria Ivete Ribeiro de Oliveira por ocasião da outorga do Título de Sócio Honorário da ABEn/1975. Rev. Bras. Enf., Rio de Janeiro, 28: 25-27, 1975.

Maria Ivete,

Dentre todas as incumbências que temos recebido da Associação Brasileira de Enfermagem, nenhuma nos trouxe tanta satisfação como a de hoje. Ao saudá-la, no momento em que lhe é conferido o título de Sócio Honorário, a mais alta láurea de nossa Associação, o fazemos com a alegria de quem vê realizarem-se seus próprios desejos e previsões, um ato de justiça pelos relevantes serviços que a colega vem prestando à classe.

Muito feliz a coincidência deste evento realizar-se em seu Estado e em sua querida Salvador. A homenagem toma o cunho de um preito à moderna enfermeira baiana, produto mesclado do patriotismo heróico de uma Ana Neri, com a eficiência do profissional universitário, científica e tecnicamente preparado para o seu importante ministério na sociedade, no campo específico da saúde.

Há certas pessoas que têm o dom de permanecer junto a nós no tempo, em- bora distanciadas pelo espaço. A homenageada de hoje pode não ser ainda conhecida pessoalmente por todas as enfermeiras brasileiras, mas todas, de uma maneira ou de outra, sofreram a influência de seus exemplos e ensinamentos, durante sua atividade profissional como enfermeira e como docente. Pode parecer que essa atuação se tenha feito sentir mais aqui, em Salvador, onde vem se destacando como membro ativo de sua associação de classe, como enfermeira eficiente e dedicada, grande educadora, administradora, cidadã comum e, agora, cidadã cívica. Entretanto, sua contribuição como coordenadora da Comissão de Educação da ABEn por dois períodos consecutivos, precisamente na época em que se estudava e discutia a revisão do currículo mínimo de enfermagem, tornou-a figura de grande importância na enfermagem brasileira, pela maneira como se conduziu no acompanhamento de todo o processo. Os fatos à margem da história, conhecidos e interpretados por uma minoria, constituem, muitas vezes, instrumentos-cha-

* Vice-Presidente da Associação Brasileira de Enfermagem. 
CARVALHO, A. C. - Apresentação da profa. Maria Ivete Ribeiro de Oliveira por ocasiāo da outorga do Título de Sócio Honorário da ABEn/1975. Rev. Bras. Enf., Rio de Janeiro, 28: 25-27, 1975.

ve na tomada de decisões. No caso em foco, a atuação de Maria Ivete foi muito mais significativa do que pode parecer à primeira vista e trouxe reais benefícios para a profissão.

A Associação Brasileira de Enfermagem é um corpo único, que se alimenta e se revitaliza por meio do esforço e do trabalho individualizado de cada uma suas células vitais, os associados, agrupados em Distritos e Seções. A liderança exercida por qualquer das células, ou por qualquer dos grupos, reflete no todo, modificando-o, a perfeiçoando-o. E quando essa liderança é desinteressada, baseada exclusivamente no ideal de bem servir a comunidade e a própria profissão, como no caso presente, tudo o que foi realizado por Maria Ivete constitui mérito para a Associação, pela qual sempre trabalhou com zelo, desinteresse e combatividade.

Maria Ivete, que hoje exerce o cargo de Secretária do Trabalho e Bem-Estar Social do Governo do Estado da Bahia, dispensaria qualquer apresentação, se a praxe não nos obrigasse ressaltar algumas de suas realizações, ferindo, embora, sua reconhecida modéstia.

Bacharelou-se em enfermagem, em 1950, pela Escola de Enfermagem da Universidade Federal da Bahia, integrante de sua primeira turma, o grupo das pioneiras, que, coincidentemente, completa neste ano bodas de prata de formatura.

Em 1969 bacharelou.-se em filosofia, pela Universidade Católica de Salvador.

A fim de aprimorar sua formacão profissional foi agraciada com três bolsas de estudo, duas oferecidas pela Fundação Rockfeller, uma pela Organização Panamericana de Saúde. Dessa maneira, realizou estudo pós-básicos nos Estados Unidos, como estudante especial, nas Universidades da Califórnia e de Boston, e visitou, em período de observação, as Universidades da Flórida, também nos
Estados Unidos e Del Vale, em Cali, na Colômbia.

Iniciou sua carreira profissional em 1951, como enfermeira-chefe do Hospital Professor Edgard Santos, de Salvador, tendo chegado a membro do seu Conselho Deliberativo, de 1970 a 1972.

Professora, ao mesmo tempo, da Escola de Enfermagem, começou lecionando Fundamentos de Enfermagem, Enfermagem Cirúrgica e Enfermagem Obstétrica; exerceu ainda outras funções docentes ou relacionadas com a docência na mesma instituição, da qual foi vice-diretora, de 1957 a 1962, e diretora em dois mandatos consecutivos, de 1963 a 1970; nessa qualidade integrou o Conselho Universitário da UFBa.

Participou de diversas Comissões da Universidade, destacando-se sua atuação marcante na Comissão da Reforma Universitária, da qual foi membro de 1965 a 1968.

Em 1970 foi chamada a colaborar mais diretamente com a Universidade, na administração de cúpula, no cargo de Adjunto do Reitor para Assuntos de Ensino, Pesquisa e Extensão. Como tal. integrou a lista sêxtupla para escolha do Reitor, o que bem demonstra a excelência da colaboração que prestou a essa Universidade.

Participou de diversos congressos, encontros e seminários, no País e no exterior, patrocinados por entidades civis ou governamentais, inúmeras vezes na qualidade de conferencista.

Em 1973 recebeu o título de Doutor pela Escola de Enfermagem da Universidade de São Paulo, após aprovação em concurso no qual defendeu com brilhantismo a tese "A enfermeira como coordenadora da assistência ao paciente análise sociométrica multírrelacional". A relevância do tema e a qualidade da tese tornaram-na referência obrigatória nos cursos de Administração aplicada à Enfermagem; servirá, sem dúvida, de 
CARVALHO, A. C. - Apresentação da profa. Maria Ivete Ribeiro de Oliveira por ocasião da outorga do Título de Sócio Honorário da ABEn/1975. Rev. Bras. Enf., Rio de Janeiro, 28: 25-27, 1975.

fundamento para modificações, consideradas necessárias e inadiáveis, no ensino teórico-prático dessa disciplina e na estrutura organizacional dos serviços de enfermagem hospitalar.

Membro ativo da Associação Brasileira de Enfermagem, Seção da Bahia, desde $o$ início da vida profissional, foi sua presidente em dois biênios, de 1958 a 1962.

No desempenho de suas múltiplas atividades, aos dotes pessoais, de inteligência, integridade de caráter dedicação ao trabalho e humanitarismo, aliou sempre os ideais da profissão; sempre fez muito mais do que apenas cumprir o seu dever, por isso todos nós lhe devemos tanto.

A homenagem que a Associação Brasileira de Enfermagem hoje lhe presta é um justo tributo à associada que tão bem soube trabalhar pelos objetivos propostos pela própria Associação; luta pelo desenvolvimento da enfermagem brasileira em todos os seus ramos; trabalho incessante pela melhoria do ensino e da assistência de enfermagem no País; exigência na observância de alto padrāo ético no desempenho profissional; defesa dos interesses e dos direitos dos enfermeiros, e colaboração com as autoridades governamentais na solução de problemas a eles relacionados; e, sobretudo, incentivo do espírito de união e da cordialidade que devem existir entre os membros da classe.

Por tudo isto, Maria Ivete, as enfermeiras e os enfermeiros do Brasil a saúdam com carinho e admiração. 